\title{
EFFECT OF INVERSION WINDS ON TOPOGRAPHIC DETAIL AND MASS BALANCE ON INLAND ICE SHEETS*
}

\author{
By I. M. Whillans \\ (Institute of Polar Studies and Department of Geology and Mineralogy, Ohio State Univer- \\ sity, Columbus, Ohio 432 ro, U.S.A.)
}

\begin{abstract}
Steady-state gravity flow of air (inversion wind) on sloping snow-covered ice sheets is analyzed for sensitivity to local topography. Topographic features of the order of a few kilometres or less in length are too small to affect the direction and speed of this air flow. Air flow on a longer scale should however conform closely to topography. Surface roughness on ice sheets is consistent with these results. Features of length shorter than a few kilometers (drifts and sastrugi) are transient, but longer features (surface undulations) remain essentially unaltered for many years. On the longer scale, inversion wind speed and therefore the amount of drifting and blowing snow should vary with the surface slope even where slope changes by as little as $\frac{1}{10} \%$. Observed variations in surface mass balance (accumulated snow) in upper Marie Byrd Land, Antarctica, support this hypothesis.

Snow drift and inversion winds thus constitute a feed-back mechanism on the form of ice sheets and some of the topographic detail, formerly attributed to ice-flow character alone, may be in large part due to this mechanism.

RÉsumé. Effets des vents d'inversion sur la topographie de detail et le bilan de masse des calottes glaciaires insulaires. Les conditions stables d'écoulement d'air par gravité (vent d'inversion) sur les pentes enneigées des calottes glaciaires ont fait l'objet d'une analyse de sensibilité à la topographie locale. Les accidents topographiques de l'ordre de quelques kilomètres ou moins en longeur, sont trop faibles pour affecter l'équilibre de l'écoulement. L'écoulement d'air à une plus grande échelle se conformerait cependant strictement à la topographie. Le rugosité de la surface de la calotte glaciaire est en bon accord avec ses résultats. Les accidents plus courts que quelques kilomètres (congères et sastrugi) sont passagers, mais les caractères topographiques plus longs (ondulations de surface) restent fondamentalement inchangés pendant de nombreuses années. A plus longue échelle, la vitesse du vent d'inversion et par conséquent, la quantité de neige chassée et soufflée varierait avec la pente superficielle, meme avec des variations de pente aussi petites que $\frac{1}{10} \%$. Des variations dans le bilan de masse de surface (neige accumulée) dans le haut de la terre Marie Byrd dar.s l'Antarctique, confirment cette hypothèse.

Le chasse-neige et les vents d'inversion constituent donc un mécanisme d'auto-activité de la forme des calottes de glace, et quelques détails topographiques, autrefois attribués au seul caractère de l'écoulement de la glace, peuvent être pour une bonne part dus à ce mécanisme.

Zusammenfassung. Der Einfluss von Inversionswinden auf Oberflächen-Kleinformen und Massenhaushalt von Inland-Eisen. Es wird untersucht, ob die stetige, durch Schwerkraft verursachte Strömung der Luft (Inversionswind) an geneigten, schneebedeckten Eiskörpern von der örtlichen Topographie abhängig ist. Geländeformen mit einer Längsausdehnung von einigen Kilometern oder weniger sind zu klein, um die Gleichgewichtsströmung zu beeinflussen. Luftströmung in grösseren Bereichen müsste jedoch gut den Geländeformen entsprechen. Die Oberflächenrauhigkeit von Eiskörpern entspricht diesen Ergebnissen. Formen mit Längen bis zu einigen Kilometern (Anwehungen und Sastrugi) sind vorübergehend, aber längere Gebilde (Oberflächen-Undulationen) bleiben im wesentlichen für viele Jahre unverändert. Im grösseren Rahmen müsste die Geschwindigkeit des Inversionswindes und infolgedessen die Menge des Treibund Flugschnees sich mit der Oberflächenneigung ändern, selbst bei Neigungsänderungen von nur 10 \% . Beobachtungen der Veränderungen des Oberfächen-Massenhaushalts (angesammelter Schnee) im oberen Marie Byrd Land, Antarktis, stützen diese Hypothese.

Schneedrift und Inversionswinde bilden so mit der Gestalt der Eiskörper einen Rückkopplungsmechanismus, und gewisse Geländeformen, die bisher ausschliesslich der Eisbewegung zugeschrieben wurden, könnten grossenteils von diesem Mechanismus verursacht sein.
\end{abstract}

\section{INTRODUCTION}

It has long been known that local mass balance (net snow accumulation) variation is closely related to local topographic variation on inland ice sheets (Schytt, 1955; Swithinbank, 1959; B'ack and Budd, 1964; Gow and others, 1972). Where topography is pronounced this may be due to orographic effects on precipitating air masses. However mass balance is related to slope even far from sources of precipitation and where slope changes are very small (Seckel and Stober, [1969]). Mass balance is, moreover, greater where slope is less, and the U.S.A.

* Contribution No. 267 of the Institute of Polar Studies, Ohio State University, Columbus, Ohio 43210, 
reverse relationship would be expected from orographic interference on air masses. Mass redistribution by blowing snow and surface drift must be important in these places, but slope changes are so small that an adequate explanation for the balance pattern has been lacking.

\section{WIND RESPONSE TO SLOPE CHANGE}

Mahrt and Schwerdtfeger (1970) have studied the effect on surface winds of a surface temperature inversion. Temperature inversions are very common on ice sheets and they cause steady inversion winds, a kind of katabatic wind, inland and the related gusty-katabatic winds near ice-sheet margins. The cold surface air is denser than air of the order of $100 \mathrm{~m}$ above the surface. Due to the slope of the snow surface, air is also denser than air at the same elevation, in the down-slope direction. This latter density contrast produces a thermal wind. Mahrt and Schwerdtfeger included friction effects and allowed for wind above the friction layer (the upper geostrophic wind), and have obtained an equation for inversion wind velocity under steady-state conditions.

Inversion winds are thus governed by the slope of the snow surface and will be stronger and the wind shear will be greater where the slope is steeper. Faster wind speeds result in more snow removal by drifting and blowing snow. In the case of undulating topography, annual snow thickness will be greater where the slope is less.

In order to investigate the applicability of this hypothesis we first analyze Mahrt and Schwerdtfeger's inversion wind to determine its sensitivity to topographic variation and then, using an empirical snow-drift formula, show that calculated wind-speed changes can explain the observed mass balance variations in upper Marie Byrd Land, Antarctica.

Mahrt and Schwerdtfeger (1970) were able to obtain an analytic solution for the surfacewind regime by approximating the temperature profile above the snow surface by an exponential relationship:

$$
T=T_{0}-\Delta T_{0} \exp \left(-z^{\star}\right)
$$

In which

$$
z^{\star}=\left(\frac{s f}{K}\right)^{\natural} z,
$$

and $T$ is the temperature at height $z$ above the snow surface, $T_{0}$ is the temperature at the top of the inversion, $\Delta T_{0}$ is the temperature difference between the top and the bottom of the inversion, $K$ is the coefficient of eddy diffusivity, $f$ is the Coriolis parameter; and $s$ is an empirical dimensionless constant without a simple physical meaning which Mahrt and Schwerdtfeger set equal to unity on the basis of data from South Pole and Plateau Stations, Antarctica (Schwerdtfeger, 1968, 1970). For generality, we will carry $s$ through the computations.

The pressure gradient force due to a temperature inversion on a very gently sloping surface is

$$
\begin{aligned}
\mathbf{P}_{T} & =-g \frac{T_{0}-T}{\bar{T}} \boldsymbol{\alpha} \\
& =-f C \exp \left(-z^{\star}\right) \boldsymbol{\alpha}
\end{aligned}
$$

in which $C=g \Delta T_{0} / f T$, and $g$ is the magnitude of the acceleration due to gravity, $T$ is mean temperature, and $\alpha$ is the surface-slope vector, directed up the slope.

Mahrt and Schwerdtfeger (1970) solved the equation for dynamic equilibrium. For the southern hemisphere, expressing vectors by complex numbers $(i=(-1)$, their solution for air velocity is:

$$
\mathbf{u}=\mathbf{u}_{g h}+\frac{C}{s+\mathrm{i}} \exp \left(-z^{\star}\right) \boldsymbol{\alpha}+\mathbf{b}_{\mathbf{1}} \exp \left[(\mathrm{I}-\mathrm{i}) \mathcal{J} z^{\star}\right]+\mathbf{b}_{2} \exp \left[(\mathrm{i}-\mathbf{1}) \mathcal{J} z^{\star}\right]
$$


where $\mathcal{f}=(2 s)^{-1}$ and $\mathbf{u}_{g h}$ is the upper geostrophic wind velocity. This is essentially an Ekman spiral with the effect of the thermal wind due to the temperature inversion included. The constants $\mathbf{b}_{1}$ and $\mathbf{b}_{2}$ are determined by the boundary conditions, $\mathbf{u}=0$ at $z=0$, and $\partial^{2} \mathbf{u} / \partial z^{2}=\mathbf{o}$ at the top of the inversion layer at $z=h$, (or $\left.z^{\star}=h^{\star}\right)$. From which:

$$
\left.\begin{array}{l}
\mathbf{b}_{\mathbf{1}}=\frac{-\frac{\mathrm{i} s C}{s+\mathrm{i}} \boldsymbol{\alpha} \exp \left[(\mathrm{I}-\mathrm{i}) f h^{\star}-h^{\star}\right]+\frac{C}{s+\mathrm{i}} \boldsymbol{\alpha}+\mathbf{u}_{g h}}{\exp \left[2(\mathrm{I}-\mathrm{i}) 7 h^{\star}\right]-\mathrm{I}}, \\
\mathbf{b}_{2}=-\frac{C}{s+\mathrm{i}} \boldsymbol{\alpha}-\mathbf{u}_{g h}-\mathbf{b}_{1} .
\end{array}\right\}
$$

The constant $\mathbf{b}_{1}$ is negligibly small for most practical examples.

Consider the reaction of this wind to slope changes. A given wind $\mathbf{u}$, would be in equilibrium with a slope $\alpha$. And $\alpha$ may be found from Equations (I) and (2):

$$
\boldsymbol{\alpha}=\frac{(s+\mathrm{i}) \mathbf{u}}{C\left\{\mathbf{d} \exp \left[(\mathrm{I}-\mathrm{i}) \mathcal{J} z^{\star}\right]-(\mathbf{d}+\mathrm{I}) \exp \left[(\mathrm{i}-\mathrm{I}) \mathcal{J} z^{\star}\right]+\exp \left(-z^{\star}\right)\right\}}+\text { functions of } \mathbf{u}_{g h} \text { and } z^{\star}
$$

in which

$$
\mathbf{d} \equiv \frac{\mathrm{I}-\mathrm{i} s \exp \left[(\mathrm{I}-\mathrm{i}) J h^{\star}-h^{\star}\right]}{\exp \left[2(\mathrm{I}-\mathrm{i}) 7 h^{\star}\right]-\mathrm{I}},
$$

which is also usually negligibly small.

If the actual slope is $\boldsymbol{\alpha}^{\prime}$, then there will be an unbalanced pressure gradient force:

$$
\Delta \mathbf{P}_{T}=-f C \exp \left(-z^{\star}\right)\left(\boldsymbol{\alpha}^{\prime}-\boldsymbol{\alpha}\right)
$$

causing an acceleration of the air mass:

$$
\frac{\mathrm{d} \mathbf{u}}{\mathrm{d} t}=\Delta \mathbf{P}_{T}
$$

where $t$ represents time.

Substituting in this, one obtains a differential equation in $\mathbf{u}$ :

$$
\begin{gathered}
\frac{\mathrm{d} \mathbf{u}}{\mathrm{d} t}-f(s+\mathrm{i})\left\{\mathbf{d} \exp \left[(\mathrm{I}-\mathrm{i}) \mathcal{J} z^{\star}+z^{\star}\right]-(\mathbf{d}+\mathrm{I}) \exp \left[(\mathrm{i}-\mathrm{I}) \mathcal{F} z^{\star}+z^{\star}\right]+\mathrm{r}\right\}^{-1} \mathbf{u} \\
=\text { functions of } \mathbf{u}_{g h}, z^{\star} \text { and } \boldsymbol{\alpha}^{\prime}
\end{gathered}
$$

whose solution is of the form:

$$
\mathbf{u}=\mathbf{u}_{0} \exp \left(-t / \tau_{\mathrm{m}}\right) \exp \left(-\mathrm{i} t / \tau_{\mathrm{d}}\right)+\text { functions of } \mathbf{u}_{g h} \text { and } \boldsymbol{\alpha}^{\prime} .
$$

In which $\mathbf{u}_{0}$ is the velocity vector that would be in equilibrium with $\alpha$, and $I / \tau_{m}$ and $i / \tau_{d}$ are the real and imaginary parts, respectively, of the coefficient of $\mathbf{u}$ in Equation (3).

For high latitudes, wind near the snow surface $(z=\mathrm{I} \mathrm{m}), K=1 \mathrm{O}^{-1} \mathrm{~m}^{2} \mathrm{~s}^{-1}$, and $s$ in the range 0.5 to 10, which fits all the temperature profiles in Schwerdtfeger (1970), the decay constant for wind speed $\tau_{\mathrm{m}}$ is of the order of $1 \mathrm{I}^{2}$ to $\mathrm{IO}^{3} \mathrm{~s}$, and for any example the wind direction decay $\tau_{\mathrm{d}}$ is several times longer. The typical inversion wind of $10 \mathrm{~m} \mathrm{~s}^{-1}$ is thus sensitive to slope changes over distances of the order of $\mathrm{I}$ to $\mathrm{I} 0 \mathrm{~km}$ and responds first by a change in wind speed rather than in wind direction.

The response times depend chiefly upon the Coriolis parameter, the coefficient of eddy diffusivity, the parameter $s$, and height. Response is fastest near the snow surface. Neither the strength of the inversion nor the surface slope affects the response time.

Since ice sheets occur at high latitudes, the Coriolis parameter varies within narrow limits and the decay times and hence the size distribution of topographic features affecting inversion winds will be everywhere much the same. 


\section{SNOW TRANSPORT}

Budd and others (1966), in their study of snow drifting at Byrd Station, Antarctica, found that more snow is carried by faster winds, according to:

$$
Q=0.015^{2}(1.23)^{u_{10}} \mathrm{~kg} \mathrm{~m}^{-1} \mathrm{~s}^{-1}
$$

where $Q$ is the mass flux of snow passing through a section indefinitely high, perpendicular to the wind direction, and $u_{10}$ is the wind speed at $z=10 \mathrm{~m}$. On steeper slopes winds are faster and more snow can be transported. Where the slope decreases, by an amount $-\Delta \alpha$, snow will be deposited at a rate:

$$
\begin{aligned}
\Delta Q & =\frac{\mathrm{d} Q}{\mathrm{~d} \alpha} \Delta \alpha \\
& =0.003 \mathrm{I} 5(1.23) u_{10} \frac{\mathrm{d} u_{\mathrm{I} 0}}{\mathrm{~d} \alpha} \Delta \alpha \mathrm{kg} \mathrm{m}^{-1} \mathrm{~s}^{-1} .
\end{aligned}
$$

In upper Marie Byrd Land, West Antarctica, slopes change by $0.00 \mathrm{I}$ in $3 \mathrm{~km}$. Such a change in slope changes the inversion wind at the $10 \mathrm{~m}$ height by $\mathrm{I} \mathrm{m} \mathrm{s}^{-1}$ (Equation (I)), and the mass of drift in transport by more than $10^{-2} \mathrm{~kg} \mathrm{~m}^{-1} \mathrm{~s}^{-1}$. If this snow is deposited over that same distance of $3 \mathrm{~km}$, local mass balances should vary by $100 \mathrm{~kg} \mathrm{~m}^{-2} \mathrm{a}^{-1}$. Measured mass balances for a whole year vary by about $20 \mathrm{~kg} \mathrm{~m}^{-2} \mathrm{a}^{-1}$ (Fig. I), which could be explained by this mechanism operating for $20 \%$ of the year.

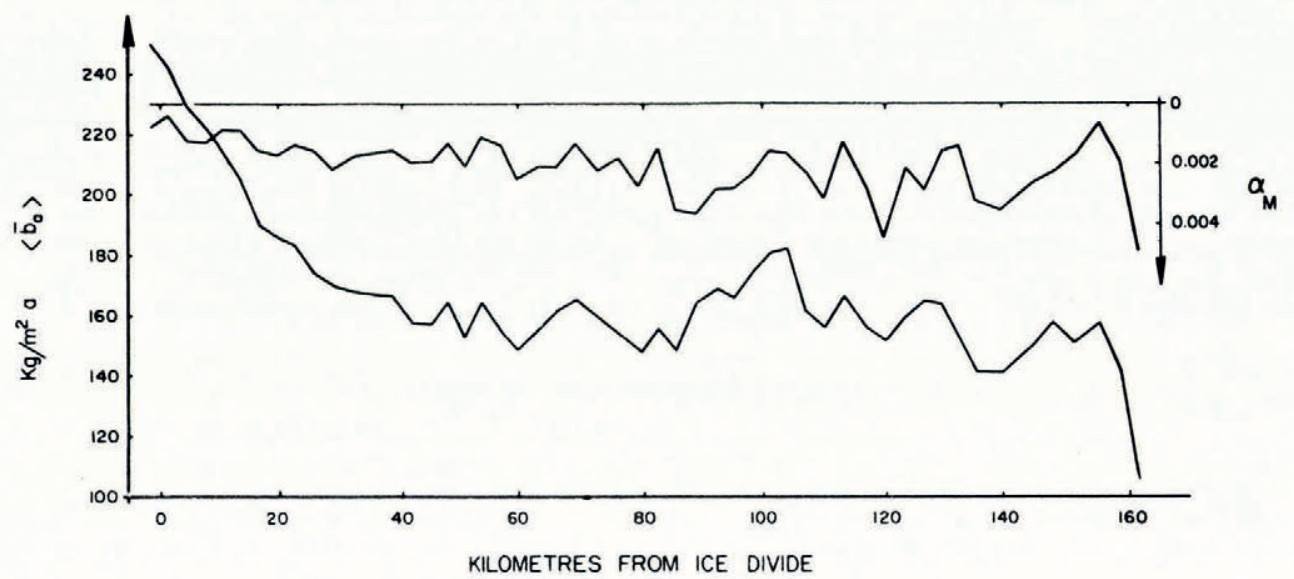

Fig. I. Surface balance, $\left\langle b_{\mathrm{a}}\right\rangle$, and maximum surface slope $\alpha_{\mathrm{m}}$ (plotted upside down for convenience), against distances from the ice crest. Both are means for $3 \mathrm{~km}$ by $3 \mathrm{~km}$ squares. Data from a travcrse north-east of "Byrd" station, Antarctica.

\section{Discussion}

Wind and temperature data for "Byrd" station are available, but have not been studied with respect to inversion-wind frequency, but it is certain that they occur during more than $20 \%$ of the year (Rubin and Weyant, 1965 , fig. 103, p. $3^{80}$ ). The mechanism described above is more efficient than the data indicate. Perhaps the complementary process of snow erosion and inclusion in drift transport has a much longer time constant than that for snow deposition. The explanation may be more likely that, in the absence of snow precipitation, snow erosion on the steeper slopes becomes more difficult with time, as older and more sintered snow is uncovered, so that snow redistribution is principally confined to occasions of inversion conditions with current or very recent snow precipitation. 
The balance variations will, with time, affect the topography. Black and Budd (1964) treated this problem by assuming that balance variations are proportional to slope variations. Equation (5) supports this assumption because the derivative $\mathrm{d} u_{\mathrm{I}} / \mathrm{d} \alpha$ obtained from Equations (I) and (2) does not depend on slope $\alpha$. Their treatment applied to our data (Fig. I) suggests a migration of the undulations up-stream at about $20 \mathrm{~m} \mathrm{a}^{-1}$. Against this tendency, the flow of the glacier carries the undulations down-stream at 5 to $10 \mathrm{~m} \mathrm{a}^{-1}$ (Whillans, 1973) in the region where the undulations are best developed. The significance of this result is difficult to evaluate because any phase difference* between balance and slope variations reduce the speed of migration, and because variations in ice-flow character such as those suggested by Nye (1959), Robinson (1966), Robin (1967), Robin and others (1970), and Budd (1968, 1970) are not considered in the theory.

\section{Conclusion}

(I) Inversion winds are sensitive to slopes measured on the scale of $\mathrm{I} \mathrm{km}$ or longer and respond to changes in slope first in wind speed and second in wind direction change.

Short-length features such as snow drifts and sastrugi do not affect inversion winds. These features are well known to be transient both in size and position.

On longer scales changes in wind speed in response to slope change alter the snowcarrying ability of the wind and snow is preferentially deposited where slope decreases.

Over $20 \mathrm{~km}$ and longer, the general shape of the ice sheet is affected by snow removal by inversion winds (Mahrt and Schwerdtfeger, 1970) but is also governed by ice-flow and climatologic considerations (for example Nye, 1959; Hughes, 1973). Note that the balance is highest in the region of the ice divide where inversion winds are not so well developed due to smaller mean slope.

(2) On the scale of the reaction length of wind to slope change, about $3 \mathrm{~km}$, snow accumulation is greater on the gentler slopes of surface topographic undulations. In time, this can affect the topography (Gow and Rowland, 1965), and waves in the surface topography of wavelength of two times the reaction length, or about $6 \mathrm{~km}$, should form. We suggest that surface undulations of this wavelength (Fig. I) are due to this mechanism. The positions of the undulations are however probably controlled by ice base irregularities and ice-flow variations, $\uparrow$ but the form of the undulations is controlled by inversion winds.

\section{AGKnowledgements}

I thank C. Bull, R. A. Hamilton, T. Hughes, M. McSaveney, and W. Schwerdtfeger for help and comment. This work was supported by National Science Foundation Grant GV26137X awarded to The Ohio State University Research Foundation and the Institute of Polar Studies.

MS. received 18 June 1973 and in revised form 20 May 1974

\footnotetext{
* The inversion wind may be able to anticipate slope changes because the driving force for the wind is due to the temperature difference between the snow surface and the air above the surface at points down-slope.

$\dagger$ The positions of such undulations have been repeatedly measured in Greenland (Seckel and Stober, [1969]) and in Marie Byrd Land, Antarctica (Southard, 1968) and are stable on the time scale of the surveys (ten and five years).
} 


\section{REFERENGES}

Black, H. P., and Budd, W. F. 1954 . Accumulation in the region of Wilkes, Wilkes Land, Antarctica. Journal of Glaciology, Vol. 5, No. 37, p. 3-15.

Budd, W. F. 1968. The longitudinal velocity profile of large ice masses. Union de Géodésie et Géophysique Internationale. Association Internationale d'Hydrologie Scientifique. Assemblée générale de Berne, 25 sept. -7 oct. 1967. [Commission de Neiges et Glaces.] Rapport et discussions, p. 58-77.

Budd, W. F. 1970. Ice flow over bedrock perturbations. Journal of Glaciology, Vol. 9 No. 55, p. $29-48$.

Budd, W. F., and others. Ig66. The Byrd snow drift project: outline and basic results, by W. F. Budd, W. R. J. Dingle and U. Radok. (In Rubin, M. J., ed. Studies in Antarctic meteorology. Washington, D.C., American Geophysical Union, p. 71-134. (Antarctic Research Series, Vol. 9.))

Gow, A. J., and Rowland, R. 1965 . On the relationship of snow accumulation to surface topography at "Byrd station", Antarctica. Journal of Glaciology, Vol. 5, No. 42, p. 843-47.

Gow, A. J., and others. 1972. Snow accumulation at "Byrd" station, Antarctica, by A. J. Gow, F. de Blander, G. Crozaz and E. [E.] Picciotto. Fournal of Glaciology, Vol. 11, No. 61, p. 59-64.

Hughes, T. J. 1973. Is the West Antarctic ice sheet disintegrating? fournal of Geophysical Research, Vol. 78, No. 33, p. $7884-9$ 10.

Mahrt, L. J., and Schwerdtfeger, W. 1970. Ekman spirals for exponential thermal wind. Boundary-Layer Meteorology, Vol. 1, No. 2, p. 137-45.

Nye, J. F. I959. The motion of ice sheets and glaciers. Journal of Glaciology, Vol. 3, No. 26, p. 493-507.

Robin, G. de Q. 1967 . Surface topography of ice sheets. Nature, Vol. 215, No. 5105, p. 1029-32.

Robin, G. de Q., and others. 1970. Radio echo exploration of the Antarctic ice sheet, by G. de Q. Robin, C. W. M. Swithinbank and B. M. E. Smith. (In [Union Géodésique et Géophysique Internationale. Association Internationale d'Hydrologie Scientifique.] [International Council of Scientific Unions. Scientific Committee on Antarctic Research. International Association of Scientific Hydrology. Commission of Snow and Ice.] International Symposium on Antarctic Glaciological Exploration (ISAGE), Hanover, New Hampshire, U.S.A., 3-7 September 1968,

p. $\left.97^{-1} 15.\right)$
Robinson, E. S. 1966. On the relationship of ice-surface topography to bed topography on the South Polar plateau. Journal of Glaciology, Vol. 6, No. 43, p. 43-54.

Rubin, M. J., and Weyant, W. S. 1965. Antarctic meteorology. (In Hatherton, T., ed. Antarctica. London, Methuen; New York, Frederick A Praeger, p. 375-401.)

Schwerdtfeger, W. 1968. New data on the winter radiation balance at the South Pole. Antarctic Journal of the United States, Vol. 3, No. 5, p. 193-94.

Schwerdtfeger, W. 1970. Die temperaturinversion über dem Antarktischen Plateau und die Struktur ihres Windfeldes. Meteorologische Rundschau, Bd. 23, Ht. 6, p. 164-71.

Schytt, V. 1955. Glaciological investigations in the Thule Ramp area. U.S. Snow, Ice and Permafrost Research Establishment. Report 28.

Seckel, H., and Stober, M. [1969.] Höhenänderung des grönländischen Inlandeises 1959-1968. Polarforschung, Bd. 6, Jahrg. 38, Nr. 1-2, 1968, p. $215^{-21}$.

Southard, R. B., jr. 1968. Topographic mapping field operations, 1967-1968. Antarctic Journal of the United States, Vol. 3, No. 4, p. II 1 .

Swithinbank, C. W. M. 1959. Glaciology. I. The regime of the ice sheet of western Dronning Maud Land as shown by stake measurements. Norwegian-British-Swedish Antarctic Expedition, 1949-52. Scientific Results, Vol. 3, E, p. $121-44$.

Whillans, I. M. 1973. State of equilibrium of the west Antarctic inland ice sheet. Science, Vol. 182, No. 41 I1, p. $476-79$. 